\title{
Some aspects of the epidemiology of ulcerative colitis
}

During the last 20 years attention has focused on the aetiology of Crohn's disease. Numerous epidemiological studies have been conducted and it is now estimated that 20000 people may be affected by the condition in Britain. Ulcerative colitis is a much commoner disease, affecting as many as 50-60 000 people and interest in its aetiology has recently increased. The disease often affects young people after puberty and medical treatment is empirical. Surgical resection of the colon may be regarded as curative and there are at least 12000 people with an ileostomy in the United Kingdom, many of whom have difficulty in coping with their stoma. ${ }^{1}$ This review examines epidemiological data which may give some indication of possible causal factors.

\section{Studies of incidence and prevalence}

Comparison of epidemiological studies is often complicated by the exclusion of patients with proctitis (Table 1). Many patients with proctitis have a mild illness and never attend hospital. As a consequence the diagnosis may not be confirmed and such cases have seldom been considered in epidemiological studies. Before the recognition of campylobacter colitis in the mid $1970 \mathrm{~s}^{30}$ it is likely that such cases were occasionally included in some studies. In recent investigtions only patients with recurrent attacks of colitis or proctitis have been included.

In most communities of Anglo Saxon origin in north western Europe, North America, and New Zealand the incidence of ulcerative colitis ranges from five to eight cases/100 000/year (Table 1), but in some areas of northern England ${ }^{3}$ and Scotland ${ }^{4}$ the disease is commoner with figures as high as 11 and $15 / 10^{5}$ /year. A study from Norway ${ }^{12}$ has reported a similar incidence in Bergen. Despite the identification of new bacterial causes of diarrhoea the incidence of ulcerative colitis has either remained constant or even increased gradually over the decades and this is in contrast to Crohn's disease (Table 1). ${ }^{31}$ In Scotland, ${ }^{5}$ Norway, ${ }^{11}$ Sweden $^{14}$ and Iceland ${ }^{16}$ studies conducted over periods of up to 30 years have shown a steady rise in incidence. This increased diagnosis of ulcerative colitis in some areas may be due to identification of milder cases rather than a real phenomenon, but further studies of incidence and mortality may resolve the problem.

Ulcerative colitis is uncommon in eastern European countries such as Czechoslovakia $^{19}$ and Bulgaria ${ }^{20}$ and in Southern Europe. ${ }^{21}$ This pattern is 
Some aspects of the epidemiology of ulcerative colitis

Table 1 Epidemiological studies of ulcerative colitis and proctitis

\begin{tabular}{|c|c|c|c|}
\hline & & $\begin{array}{l}\text { Incidence } \\
\left.\text { (cases } / 10^{5} / \text { year }\right)\end{array}$ & $\begin{array}{l}\text { Prevalence } \\
\text { (cases } / 10^{5} \text { pop.) }\end{array}$ \\
\hline \multicolumn{4}{|l|}{ Great Britain } \\
\hline Oxford ${ }^{2}$ & $1951-60$ & 6.5 & $79 \cdot 9$ \\
\hline North Tees ${ }^{3}$ & $1971-77$ & $15 \cdot 1$ & 99 \\
\hline GrampianRegion $^{4}$ & $1967-76$ & $11 \cdot 3$ & \\
\hline \multirow[t]{2}{*}{ Lothian Region $^{5}$} & $1968-71$ & $2 \cdot 6$ & \\
\hline & $1976-79$ & $4 \cdot 0$ & \\
\hline Cardiff Region $^{6}$ & $1968-77$ & $7 \cdot 2$ & \\
\hline \multicolumn{4}{|l|}{ Denmark } \\
\hline Denmark $^{7}$ & $1940-61$ & 1.6 (excludes proctitis) & \\
\hline Copenhagen County ${ }^{8}$ & $1961-67$ & $7 \cdot 3$ & $44 \cdot 1$ \\
\hline Copenhagen County ${ }^{9}$ & $1962-78$ & $8 \cdot 1$ & 117 \\
\hline \multicolumn{4}{|l|}{ Norway } \\
\hline Norway ${ }^{10}$ & $1946-55$ & $1 \cdot 2$ & \\
\hline \multirow[t]{2}{*}{ Norway ${ }^{11}$} & $1956-60$ & $2 \cdot 3$ & \\
\hline & $1964-69$ & $3 \cdot 3$ & \\
\hline Bergen $^{12}$ & $1976-80$ & 10 & \\
\hline \multicolumn{4}{|l|}{ Sweden } \\
\hline Malmo $^{13}$ & $1958-70$ & $6 \cdot 4$ & \\
\hline \multirow[t]{2}{*}{ Stockholm County ${ }^{14}$} & 1955 & 0.9 & \\
\hline & 1974 & $5 \cdot 7$ & \\
\hline \multicolumn{4}{|l|}{ Finland } \\
\hline Finland $^{15}$ & 1967 & $4 \cdot 8$ & \\
\hline \multicolumn{4}{|l|}{ Iceland } \\
\hline \multirow{3}{*}{ Iceland $^{16}$} & $1950-59$ & $2 \cdot 8$ & 8.4 \\
\hline & $1960-69$ & $4 \cdot 7$ & \\
\hline & $1970-79$ & $7 \cdot 6$ & $122 \cdot 2$ \\
\hline \multicolumn{4}{|l|}{ Germany } \\
\hline \multirow{3}{*}{$\begin{array}{l}\text { Marburg/Lahn }{ }^{17} \\
\text { Halle-Wittenberg }{ }^{18}\end{array}$} & $1962-75$ & $5 \cdot 1$ & $48 \cdot 8$ \\
\hline & 1980 & & $23 \cdot 6$ (men) \\
\hline & & & $26 \cdot 1$ (women) \\
\hline \multicolumn{4}{|l|}{ Czechoslovakia } \\
\hline North Bohemia ${ }^{19}$ & 1978 & $1 \cdot 3$ & $23 \cdot 9$ \\
\hline \multicolumn{4}{|l|}{ Bulgaria } \\
\hline Bulgaria $^{20}$ & 1981 & & 6 \\
\hline \multicolumn{4}{|l|}{ Italy } \\
\hline Bologna $^{21}$ & $1972-73$ & $1 \cdot 9$ & \\
\hline \multicolumn{4}{|l|}{ United States of America } \\
\hline \multirow{4}{*}{$\begin{array}{l}\text { Bessemer Alabama } \\
\text { Baltimore }^{23}\end{array}$} & $1952-58$ & $3 \cdot 1$ & 22 \\
\hline & $1960-63$ & & \\
\hline & White men & $3 \cdot 9$ & \\
\hline & White women & $5 \cdot 2$ & \\
\hline \multirow[t]{3}{*}{ Fifteen Areas Study ${ }^{24}$} & 1973 & & \\
\hline & White men & $3 \cdot 7$ & \\
\hline & White women & $3 \cdot 4$ & \\
\hline Rochester, Minnesota ${ }^{25}$ & $1935-64$ & $7 \cdot 2$ & $55 \cdot 3$ \\
\hline South Africa & & & \\
\hline Cape Town ${ }^{26}$ & $1970-79$ & & \\
\hline & Whites & $2 \cdot 4$ & \\
\hline & Coloureds & 1.6 & \\
\hline & Jews & $10 \cdot 4$ & \\
\hline Israel & & & \\
\hline Tel-Aviv-Jafo ${ }^{27}$ & $1961-70$ & $3 \cdot 7$ & $37 \cdot 4$ \\
\hline New Zealand & & & \\
\hline New Zealand ${ }^{28}$ & 1962 & $5 \cdot 5$ & \\
\hline Auckland ${ }^{29}$ & $1969-78$ & & \\
\hline & Caucasians & $5 \cdot 4$ & \\
\hline & Polynesians & $0 \cdot 2$ & \\
\hline
\end{tabular}

Published reports of epidemiological studies of ulcerative colitis and proctitis throughout the world. 
similar to that described for Crohn's disease and international comparisons $^{32} 33$ of mortality rates have shown that where Crohn's disease is common, so is ulcerative colitis. Particular attention in the future will focus on such countries as Spain and Portugal; Central and South America are of interest for similar reasons.

\section{Urban rural differences in the distribution of ulcerative colitis}

In 1963 Acheson $^{34}$ reviewed over 500 American veterans with ulcerative colitis and noted a significant deficiency of those with a farming background. In New Zealand ${ }^{28}$ the incidence of colitis in towns was significantly greater than country areas. Similar findings have been reported from Baltimore, ${ }^{35}$ Marburg, ${ }^{17}$ Bologna, ${ }^{21}$ the Grampian region, ${ }^{4}$ and Finland, ${ }^{15}$ but not Oxford. ${ }^{2}$ The increased urban prevalence of ulcerative colitis is not because of better diagnostic facilities, but its significance is uncertain. In today's society there is a much greater movement between urban and rural communities and it has become difficult to clearly define rural areas.

\section{Immigrant studies}

Das and Montgomery ${ }^{36}$ reported 11 Pakistani and Indian patients with ulcerative colitis who had lived in England for up to 18 years but had largely retained their traditional high fibre diet. Several studies of bowel disease in immigrants are currently underway and preliminary results from Bradford $^{37}$ suggest that the prevalence of ulcerative colitis in Asian immigrants $\left(59 / 10^{5}\right)$ is similar to that seen in other British studies.

Ulcerative colitis has been reported throughout the world from as far apart as India ${ }^{38}$ and the West Indies. ${ }^{39}$ It is possible that it is as common in these countries as in western Europe, but the true prevalence is masked by other infectious causes of diarrhoea.

\section{Ulcerative colitis in Jews}

Ulcerative colitis is three to five times commoner in Jews compared with other citizens living in western communities (Table 2). In Israel ${ }^{27}$ the prevalence in immigrants from the West is low at $37 / 10^{5}$. The disease is, however, significantly more common in this group than among those born in Asia $\left(18 \cdot 9 / 10^{5}\right)$ or in Israel $\left(28 \cdot 5 / 10^{5}\right) .2743$ The reason for this apparent difference in susceptibility is unknown; but studies in second generation Israelis may provide some clues to aetiology.

\section{Familial prevalence}

There have been a number of reports of families in which several members have inflammatory bowel disease and it seems likely that there is a genetic predisposition to these conditions but the magnitude of the risk is uncertain. Binder et $a l^{44}$ reviewed 152 patients with ulcerative colitis compared with matched controls of the same social class. In eight families a relative was affected compared with only one in the control group. These findings have been confirmed in Stockholm ${ }^{45}$ and suggest that family 
Table 2 Ulcerative colitis in Jews

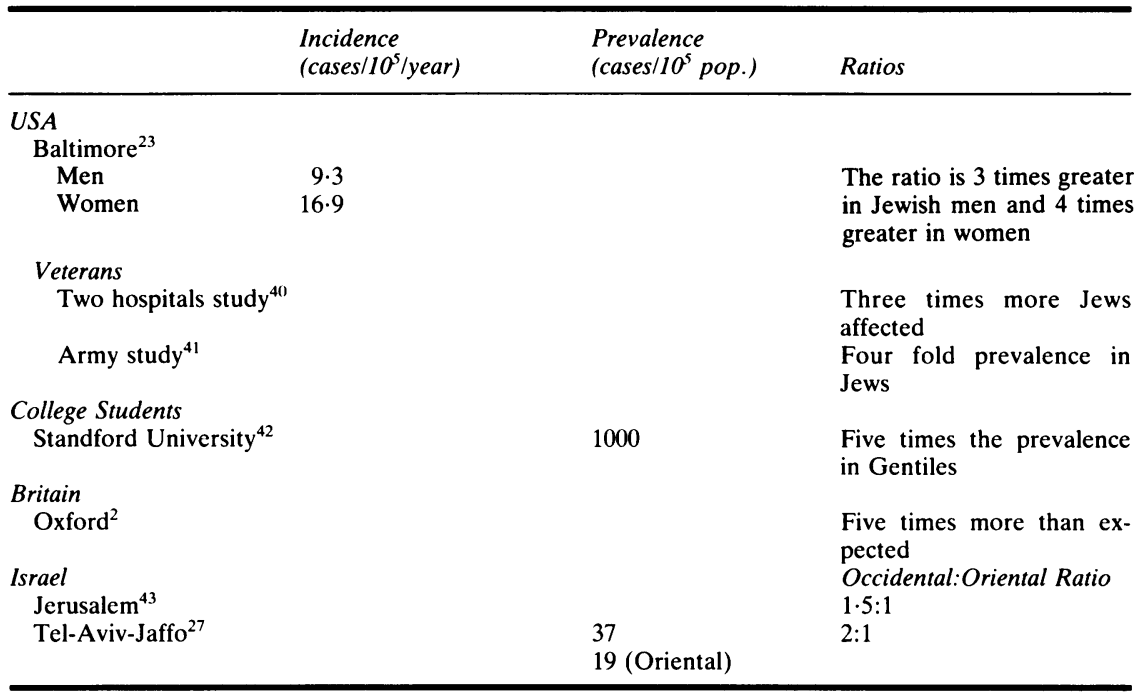

Studies which report the prevalence of ulcerative colitis in Jews and Gentiles.

members are at an increased risk of developing inflammatory bowel disease compared with other members of the community. Twin studies would be useful, but to date there have only been seven case reports. ${ }^{46}$

The relatives of patients with Crohn's disease appear to be at eight to 10 times the risk of developing ulcerative colitis compared with other people. In a community based study in Cardiff ${ }^{47}$ of 867 first degree relatives of patients with Crohn's disease seven had ulcerative colitis (prevalence = $807 / 10^{5}$ ). Similar results have been obtained in Leiden ${ }^{48}$ where the prevalence of ulcerative colitis among the parents and siblings of 379 patients with Crohn's disease was $1194 / 10^{5}$.

The relatives of patients with ulcerative colitis and with Crohn's disease are both at an eight-fold risk of developing ulcerative colitis.

\section{Crohn's disease and ulcerative colitis}

The distinction between these two conditions may be difficult, but in recent studies ulcerative colitis has been two and three times as common as Crohn's disease (Table 3). This relationship can be important in surveys where a population base is uncertain or even unknown and has been useful in studies of occupational or religious groups such as nurses ${ }^{49}$ and Mormons. ${ }^{50}$ It may be of particular value in countries where the detection of cases is impaired by poor central documentation.

Ulcerative colitis remains as much an enigma as Crohn's disease. There is some evidence that it is immunologically mediated and that some people are genetically susceptible. The roles of cigarette smoking ${ }^{51-55}$ early weaning $^{56}$ and dietary factors ${ }^{58-60}$ remain unclear. It is over 100 years since Sir Samuel Wilkes ${ }^{61}$ first described the symptoms and pathology of this condition; perhaps during the next century we will discover its cause. 
Table 3 The ratio of ulcerative colitis to Crohn's disease at various centres

\begin{tabular}{|c|c|}
\hline & Ratio \\
\hline $\begin{array}{l}\text { Great Britain } \\
1 \text { Oxford } \\
2 \text { North Tees } \\
3 \text { Grampian Region } \\
4 \text { Cardiff Region }\end{array}$ & $\begin{array}{l}8.0 \\
2.8 \\
2.3 \\
1.5\end{array}$ \\
\hline $\begin{array}{l}\text { Scandinavia } \\
1 \text { Copenhagen } \\
2 \text { Malmo } \\
3 \text { Stockholm County } \\
4 \text { Bergen }\end{array}$ & $\begin{array}{l}3.0 \\
1.6 \\
1.6 \\
2.9\end{array}$ \\
\hline $\begin{array}{l}\text { Germany } \\
1 \text { Marburg }\end{array}$ & 1.7 \\
\hline $\begin{array}{l}\text { Italy } \\
\quad 1 \text { Bologna }\end{array}$ & $2 \cdot 3$ \\
\hline $\begin{array}{l}\text { Israel } \\
\quad 1 \text { Tel-Aviv-Jafo }\end{array}$ & $2 \cdot 8$ \\
\hline $\begin{array}{l}\text { USA } \\
\quad 1 \text { Baltimore }\end{array}$ & $2 \cdot 2$ \\
\hline
\end{tabular}

The incidence of Crohn's disease and ulcerative colitis is compared at various centres. The studies have not always been conducted simultaneously and in $\mathrm{Oxford}^{2}$ the high ratio was due to a failure to recognise colonic Crohn's disease.

I should like to thank $\mathrm{Dr}$ John Rhodes for his encouragement in undertaking this review.

J F MAYBERRY

\section{Queens Medical Centre}

University Hospital of Nottingham

Nottingham

Received for publication 1 November 1984

Address for correspondence: Dr J F Mayberry, Department of Gastroenterology, Queens Medical Centre, University Hospital of Nottingham, Clifton Boulevard, Nottingham NG7 2UH.

\section{References}

1 Mayberry JF, Rhodes J. Aspects of the ileostomy appliance. A survey of the patients' difficulties. The Practitioner 1978; 220: 958-61.

2 Evans JG, Acheson ED. An epidemiological study of ulcerative colitis and regional enteritis in the Oxford area. Gut 1965; 6: 311-24.

3 Devlin HB, Datta D, Dellipiani AW. The incidence and prevalence of inflammatory bowel disease in North Tees Health District. World J Surg 1980; 4: 183-93.

4 Sinclair TS, Brunt PW, Mowat NAG. Non specific proctocolitis in Northeastern Scotland: A community study. Gastroenterology 1983; 85: 1-11.

5 Entrican J, Sircus W. Changes in the epidemiology and pattern of presentation of inflammatory bowel disease. Abstracts of International workshop of the epidemiology and genetics of inflammatory bowel disease. Liverpool: Liverpool Medical Institution Glaxo, $1983 ; 46$

6 Morris TJ, Rhodes J. Incidence of proctocolitis in the Cardiff Region, 1968-1977. [Abstract]. Gut 1980; 21: A923.

7 Lindenberg J, Aagaard P. Colitis ulcerosa i Danmark. Morbidet, letalitet og malignitet. Ugesskr Laeger 1964; 126: 781-4. 
8 Bonnevie O, Riis P, Anthonisen P. An epidemiological study of ulcerative colitis in Copenhagen County. Scand J Gastroenterol 1968; 3: 432-8.

9 Binder V, Both H, Hansen PK, Hendriksen C, Kreiner S, Torp-Pedersen K. Incidence and prevalence of ulcerative colitis and Crohn's disease in the County of Copenhagen 1962-1978. Gastroenterology 1982; 83: 563-8.

10 Ustvedt HJ. Ulcerative colitis: a study of all cases discharged from Norwegian hospitals in the ten year period 1946-1955. In: Pemberton J, Williams H, eds Recent studies in epidemiology Oxford: Blackwell Scientific Publications 1958: 23-34.

11 Myren J, Gjone E, Hertzberg JN, Rygvold O, Semb LS, Fretheim B. Epidemiology of ulcerative colitis and regional enterocolitis (Crohn's disease) in Norway. Scand Gastroenterol 1971; 6: 511-4.

12 Skarstein A, Arnesjo B, Burhol P, et al. The incidence of ulcerative colitis and Crohn's disease in an urban population. Scand J Gastroenterol 1982; 17: suppl 78: 349.

13 Brahme F, Lindstrom C, Wenckert A. Crohn's disease in a defined population. An epidemiological study of incidence, prevalence, mortality and secular trends in the City of Malmo, Sweden. Gastroenterology 1975; 69: 342-51.

14 Nordenvall B, Berglund M, Brostrom $\mathrm{O}$ et al. Epidemiology of ulcerative colitis in Stockholm County Scand J Gastroenterol 1982; 17: suppl 78: 282.

15 Linden G. Ulcerative colitis in Finland 11. One year incidence in all hospitals. Dis Colon Rectum 1971; 14: 264-6.

16 Bjornsson S, Thorgeirsson T. Colitis ulcerosa i Island. Epidemiologisk undersokning 1950-1979. Nord Med 1983; 98: 298-301.

17 Brandes JW, Lorenz-Meyer K. Epidemiologische aspekte zur enterocolitis regionalis Crohn und colitis ulcerosa in Marburg/Lahn (FRG) zwischen 1962 und 1975. Z Gastroenterol 1983; 21: 69-78.

18 Schneider VW. Epidemiologie chronisch entzundlicher Darmerkrankungen $Z$ Gesamte Inn Med 1980; 36: suppl: 228-30.

19 Bitter J, Hulec J. Ulcerozni kolitida v severoceskem kraji. Cesk Gastroenterol 1980; 34: $137-44$.

20 Yavorska N, Djadjova-Boneva M. Epidemiological study of ulcerative colitis in Bulgaria. Scand J Gastroenterol 1982; 17: suppl 78: 282.

21 Lanfranchi GA, Michelini M, Brignola C, Campieri M, Cortini C, Marzio L. Uno studio epidemiologico sulle malattie inflammatorie intestinali nella provincia di Bologna. $G$ Clin Med 1976; 57: 235-45.

22 McMahon JM, Morton B. Ulcerative colitis in a southern general hospital and a southern industrial-rural area. A concept of etiology and an attempt at a geography of the disease. Am J Gastroenterol 1959; 31: 183-91.

23 Monk M, Mendeloff AI, Siegel CI, Lilienfeld A. An epidemiological study of ulcerative colitis and regional enteritis among adults in Baltimore 1 . Hospital incidence and prevalence, 1960 to 1963. Gastroenterology 1967; 53: 198-210.

24 Garland CF, Lilienfeld AM, Mendeloff AI, Markowitz JA, Terrell KB, Garland FC. Incidence rates of ulcerative colitis in fifteen areas of the United States. Gastroenterology 1981; 81: 1115-24.

25 Sedlack RE, Nobrega FT, Kurland LT, Sauer WG. Inflammatory colon disease in Rochester, Minnesota, 1935-1964. Gastroenterology 1972; 62: 935-41.

26 Wright JP, Marks IN, Jameson C, Garisch JAM, Burns DG, Kottler RE. Inflammatory bowel disease in Cape Town, 1975-1980. Part 1. Ulcerative colitis. S Afr Med J 1983; 63: 223-6.

27 Gilat T, Ribak J, Benaroya Y, Zemishlany Z, Weissman I. Ulcerative colitis in the Jewish population of Tel-Aviv-Jafo 1. Epidemiology. Gastroenterology 1974; 66: 335-42.

28 Wigley RD, MacLaurin BP. A study of ulcerative colitis in New Zealand, showing a low incidence in Maoris. $\mathrm{Br}$ Med J 1962; 2: 228-31.

29 Tasman-Jones C, Eason R, Lee SP. Inflammatory bowel disease - ethnic variations in Auckland, New Zealand. Scand J Gastroenterol 1982; suppl 78: 350.

30 Skirrow MB. Campylobacter enteritis - a new disease. Br Med J 1977; 2: 9-11.

31 Levy JS, Rieherd L. Chronic ulcerative colitis. Comparison of cases before and after World War II. Am J Gastroenterol 1968; 50: 208-13.

32 Newcombe RG, Mayberry JF, Rhodes J. An international study of mortality from inflammatory bowel disease. Digestion 1982; 24: 73-8.

33 D'Oliveira R, Mayberry JF, Newcombe RG, Rhodes J. An international comparison of mortality from inflammatory bowel disease in the Latin speaking countries of France, Italy and Venezuela. Digestion 1984; 29: 239-41. 
34 Acheson ED, Nefzger MD. Ulcerative colitis in the United States Army in 1944. Epidemiology: comparisons between patients and controls. Gastroenterology 1963; 44: 7-19.

35 Monk M, Mendeloff AI, Siegel CI, Lilienfeld A. An epidemiological study of ulcerative colitis and regional enteritis among adults in Baltimore 11. Social and demogrpahic factors. Gastroenterology 1969; 56: 847-57.

36 Das SK, Montgomery RD. Chronic inflammatory bowel disease in Asian immigrants. Practitioner 1978; 221: 747-9.

37 Findlay JM. Inflammatory bowel disease and ileocaecal tuberculosis in Bradford. In: International workshop on the epidemiology and genetics of inflammatory bowel disease. [Abstracts]. Liverpool: Liverpool Medical Institution Glaxo, 1983: 57.

38 Tandon BN, Mathur AK, Mohapatra LN, Tandon HD, Wig KL. A study of the prevalence and clinical pattern of non-specific ulcerative colitis in northern India. Gut 1965; 6: 448-53.

39 Bartholomew C, Butler A. Inflammatory bowel disease in the West Indies. $\mathrm{Br} \mathrm{Med} \mathrm{J}$ 1979; 2: 824-5.

40 Weiner HA, Lewis CM. Some notes on the epidemiology of non-specific ulcerative colitis. An apparent increase in incidence in Jews. Am J Dig Dis 1960; 5: 406-18.

41 Acheson ED. The distribution of ulcerative colitis and regional enteritis in United States Veterans with particular reference to the Jewish religion. Gut 1960; 1: 291-3.

42 Gelpi AP. Inflammatory bowel disease among college students. West J Med 1978; 129: 369-73.

43 Birnbaum D, Groen JJ, Kauner G. Ulcerative colitis among the ethnic groups in Israel. Arch Intern Med 1960; 105: 843-8.

44 Binder V, Weeke E, Olsen JH, Anthonisen P, Riis P. A genetic study of ulcerative colitis. Scand J Gastroenterol 1966; 1: 49-56.

45 Monsen U, Berglund M, Brostrom O, Nordenvall B, Sorstad J, Hellers G. Family history of ulcerative colitis in Stockholm County. In International workshop on the epidemiology and genetics of inflammatory bowel disease. [Abstracts]. Liverpool: Liverpool Medical Institution Glaxo, 1983: 33.

46 Mayberry JF, Dew M, Morris JS. Monozygotic twins with ulcerative colitis. Postgrad Med J 1982; 58: 112-4.

47 Mayberry JF, Rhodes J, Newcombe RG. Familial prevalence of inflammatory bowel disease in relatives of patients with Crohn's disease. Br Med J 1980; 1: 84.

48 Weterman IT, Pena AS. Family occurrence in Dutch patients with Crohn's disease. Scand J Gastroenterol 1982; 17: suppl 78: 354.

49 Mayberry JF, Newcombe RG. Are nurses at an increased risk of developing inflammatory bowel disease? Digestion 1981; 22: 150-4.

50 Penny WJ, Penny E, Mayberry JF, Rhodes J. Mormons, smoking and ulcerative colitis. Lancet 1983; 2: 1315.

51 Harries AD, Baird A, Rhodes J. Non-smoking: a feature of ulcerative colitis. $\mathrm{Br} \mathrm{Med} \mathrm{J}$ 1982; 284: 706.

52 Bures J, Fixa B, Komarkova O, Fingerland A. Non-smoking: a feature of ulcerative colitis. Br Med J 1982; 285: 440.

53 Gyde SN, Allan RN. Cigarette smoking and ulcerative colitis. N Engl J Med 1983; 308: 1476.

54 Logan RFA, Edmond M, Somerville KW, Langman MJS. Smoking and ulcerative colitis. Br Med J 1984; 288: 751-3.

55 Jick H, Walker AM. Cigarette smoking and ulcerative colitis. $N$ Engl J Med 1983; 308: 261-3.

56 Acheson ED, Truelove SC. Early weaning in the aetiology of ulcerative colitis. A study of feeding in infancy in cases and controls. Br Med J 1961; 2: 929-33.

57 Whorwell PJ, Holdstock G, Whorwell GM, Wright R. Bottle feeding, early gastroenteritis and inflammatory bowel disease. $\mathrm{Br}$ Med J 1979; 1: 382.

58 Truelove SC. Ulcerative colitis provoked by milk. Br Med J 1961; 1: 154-60.

59 Thornton JR, Emmett PM, Heaton KW. Diet and ulcerative colitis. Br Med J 1980; 1: 293-4.

60 Mayberry JF, Rhodes J, Newcombe RG. Increased sugar consumption in Crohn's disease. Digestion 1980; 20: 323-6.

61 Wilkes S, Moxan W. Lectures in Pathological Anatomy. Vol 3. 672. London: J A Churchill, 1875: 672. 